\title{
DESAIN KELEMBAGAAN DALAM KOLABORASI PENCEGAHAN KEMATIAN IBU SAAT PERSALINAN
}

\author{
Rininta Andriani ${ }^{1}$, dan La Ode Syaiful Islamy ${ }^{2}$ \\ ${ }^{1}$ Universitas Dayanu Ikhsanuddin, Fakultas Kesehatan Masyarakat. D/a. Jl. Sultan Dayanu \\ Ikhsanuddin No.124 Kota Baubau, Provinsi Sulawesi Tenggara, Indonesia \\ ${ }^{2}$ Universitas Dayanu Ikhsanuddin, Fakultas Ilmu Sosial dan Ilmu Politik D/a. J1. Sultan Dayanu \\ Ikhsanuddin No.124 Kota Baubau, Provinsi Sulawesi Tenggara, Indonesia \\ E-mail: syaiful80islamy@gmail.com
}

\section{DESIGN INSTITUTIONAL IN COLLABORATION OF THE PREVENTION OF MOTHER DEATH AT CHILDBIRTH}

\begin{abstract}
Efforts to prevent maternal death during childbirth have become a serious concern of the government and society. Many factors cause maternal death; one of the factors is the lack of access to good services for maternal health, especially the punctuality of emergencies caused by being late in making decisions to get treatment, the second is late arriving at health facilities, and the third is late in getting adequate and appropriate treatment. The efforts to prevent maternal death during childbirth can be made by collaborating to design institution collaborative of maternal death prevention at first. The purpose of this research was to describe the collaborative institution design of maternal death prevention during childbirth in South Buton Regency using a qualitative method with a phenomenological approach, data collected through observation, interviews and document study and analyzed with the stages of data reduction, data display, and conclusion drawing/verification. The result showed that in designing the institution, this could be seen from society's large participation based on equality and sharing of understanding from the collaborative actors. The establishment of a limited forum resulted from discussions carried out, which was legitimated in terms of basic rules of collaboration supporter that combined between customary regulations and customs of ancestors and applicable statutory regulations.
\end{abstract}

Keywords : Design Institutional; Collaboration; Maternal death; Childbirth

\begin{abstract}
Abstrak
Upaya pencegahan kematian ibu saat persalinan telah menjadi perhatian serius pemrintah dan masyarakat. Banyak faktor yang menyebabkan tingginya kematian ibu salah satunya adalah minimnya akses pelayanan yang baik bagi kesehatan ibu terutama ketepatan waktu kegawatdaruratan yang disebabkan oleh terlambat mengambil keputusan untuk mendapatkan perawatan, yang kedua terlambat tiba di fasilitas kesehatan dan yang ketiga terlambat mendapatkan penanganan yang memadai dan tepat. Upaya pencegahan kematian ibu saat persalinan ini dapat dilakukan dengan cara berkolaborasi yang terlebih dahulu melakukan desain kelembagaan kolaborasi pencegahan kematian ibu. Tujuan penelitian ini adalah untuk mendeskripsikan desain kelembagaan kolaborasi pencegahan
\end{abstract}


kematian ibu saat persalinan di Kabupaten Buton Selatan menggunakan metode kualitatif dengan pendekatan fenomenologis data dikumpulkan melalui observasi, wawancara dan studi dokumen serta dianalisis dengan tahapan data reduction, data display, dan conclusion drawing/verification. Hasil penelitian menunjukan bahwa desain kelembagaan telah terbentuk hal ini dapat dilihat dari partisipasi masyarakat yang begitu besar yang didasarkan atas kesetaraan dan berbagi pemahaman dari para aktor kolaborasi. Kemudian terbangunnya forum terbatas hasil dari diskusi-diskusi yang kemudian terlegitimasi dalam aturan dasar pendukung kolaborasi yang menggabungkan antara aturan adat serta kebiasaan-kebiasaan nenek moyang dan peraturan perundang-undangan yang berlaku.

Kata kunci: Desain kelembagaan; Kolaborasi; Kematian Ibu; Persalinan

\section{PENDAHULUAN}

Pencegahan kematian ibu saat persalinan hingga saat ini merupakan isu utama dalam kesehatan masyarakat. Pada tahun 2017 sekitar 830 ibu meninggal disebabkan oleh kehamilan dan persalinan, sedangkan di Indonesia masih menempati posisi 305 per 100 ribu kelahiran hidup ${ }^{(1)}$. Dengan melihat keadaan tersebut dapat disimpulkan bahwa dalam setiap jam bahkan setiap hari bahkan setiap menitnya seorang ibu harus mengalami kematian yang disebabkan oleh komplikasi yang berhubungan dengan kehamilan, persalinan dan pasca kelahiran ${ }^{(2)}$.

Jika melihat profil kesehatan Sulawesi Tenggara, dalam 5 tahun terakhir kasus kematian ibu berada pada angka 65-75 orang setiap tahunnya. Pada tahun 2019, kasus kematian ibu disebabkan oleh kematian ibu bersalin sebesar 32 kasus, kematian Ibu nifas sebanyak 20 kasus dan kasus kematian Ibu hamil sebanyak 8 kasus. Bila dilihat dari Angka Kematian Ibu (AKI), Tahun 2019 Angka Kematian ibu Provinsi Sulawesi Tenggara adalah 128/100.000 $\mathrm{KH}^{(3)}$. Sedangkan di Buton Selatan penanganan Angka Kematian Ibu (AKI) yang mana pada tahun 2016 berjumlah 3 orang dengan 1.725 bayi yang lahir hidup, tahun 2017 berjumlah 3 orang dengan 1.711 bayi lahir hidup dan pada tahun 2018 berjumlah 2 orang dengan 1.712 bayi lahir hidup ${ }^{(4)}$.

Banyak faktor yang menyebabkan tingginya kematian ibu salah satunya adalah minimnya kases pelayanan kesehatan ibu yang baik terutama ketepatan waktu kegawatdaruratan yang disebabkan oleh 3 keterlambatan yaitu terlambat mengambil keputusan untuk mendapatkan perawatan, yang kedua terlambat tiba di fasilitas kesehatan dan yang ketiga terlambat mendapatkan penanganan yang memadai dan tepat ${ }^{(5)}$. Selain itu kondisi ibu saat hamil dan melahirkan sudah dalam masa risiko tinggi dan masuk dalam kriteria terlalu tua saat melahirkan ( $>35$ tahun), terlalu muda $(<20$ tahun), terlalu banyak anak ( $>4$ anak), dan terlalu rapat jarak kelahiran $(<2 \text { tahun })^{(6)}$.

Upaya pencegahan kematian ibu saat persalinan telah banyak dilakukan oleh penerintah salah satunya adalah dengan menerbitkan Peraturan Menteri Kesehatan Republik Indonesia nomor 97 Tahun 2014 pasal 46 yang menyatakan bahwa dalam rangka membantu percepatan pencapaian derajat kesehatan ibu yang optimal diperlukan peran serta masyarakat baik secara perseorangan maupun terorganisasi. Peran serta masyarakat sebagaimana dimaksud dapat berupa: program perencanaan persalinan dan pencegahan komplikasi,penyelenggaraan kelas ibu hamil, kemitraan bidan dan dukun, dan rumah tunggu kelahiran ${ }^{(7)}$, selain itu pemerintah Kabupaten Buton selatan juga telah mengeluarkan Peraturan Bupati nomor 62 Tahun 2019 Dalam Peraturan Bupati nomor 62 Tahun 2019 tentang Program Inovasi Bidang Kesehatan Gerakan Lanjut Usia 
Peduli Kesehatan Ibu dan Anak dengan melibatkan Pemerintah Daerah, Kecamatan dan Desa, Kelompok Kerja Operasional, dan fasilitator.

Salah satu cara yang dinilai akan mempercepat keberhasilan suatu program adalah dengan cara kolaborasi antara pemerintah dan beberapa aktor. Menurut Islamy, dalam menangani dan penataan masalah publik diperlukan keterlibatan selain pemerintah juga keterlibatan lembaga non pemerintah, dalam hal ini termasuk lembaga swadaya masyarakat setempat, dan lembaga adat, sebab masalah publik tidak cukup hanya dibebankan kepada pemerintah namun dibutuhkan keterlibatan semua aktor terkait dan terintegrasi ${ }^{(8)}$. Sedangkan menurut Ansel and Gash adanya perjanjian atau kerjasama dimana agensi public dan stakeholders dalam proses pembuatan keputusan kolektif yang bersifat formal, berdasarkan konsensus, dan bersifat deliberatif yang bertujuan membuat atau mengimplementasikan kebijakan public atau manajemen program/aset-aset publik ${ }^{(9)}$.

Setiap program pemerintah akan berjalan dengan baik dan memenuhi sasaran dibutuhkan keterlibatan masyarakat secara luas. Keterlibatan masyrakat ini bukan sekedar mendukung program pemerintah tetapi peran masyarakat lebih kepada peran yang lebih besar untuk kesejahteraannya. Dengan demikian desain kelembagaan sangat penting dilaksanakan untuk mengarahkan, menggerakkan, dan menciptakan iklim guna mendukung program yang dilakukan oleh masyarakat.

Saat melaksanakan kolaborasi yang melibatkan masyarakat secara luas dibutuhkan suatu desain kelembagaan yang mengacu pada protokol dan aturan dasar dalam berkolaborasi, hal ini sangat penting untuk legalitas proses kolaborasi sehingga permasalahan desain kelembagaan menjadi hal yang mendasar ${ }^{(9)}$.

Kelembagaan dalam masyarakat meliputi kesatuan unsur beserta jaringannya yang dikembangkan secara terorganisasi, meliputi Pemerintah pusat, pemerintah daerah, swasta, asosiasi, lembaga swadaya masyarakat, lembaga adat, dan masyarakat umum. Sedangkan Kelembagaan kesehatan masyarakat memiliki posisi sangat penting dalam masyarakat, dimana lembaga kesehatan ini memberikan pelayanan kesehatan dasar ditengah-tengah masyarakat. Salah satu contoh lembaga kesetahan adalah posyandu yang memiliki fungsi pemantauan kesehatan ibu hamil, pemberian imunisasi pada bayi, pelayanan kesehatan bagi lansia, serta membantu Puskesmas dalam pemenuhan pelayanan kesehatan bagi masyarakat.

Tujuan penelitian ini adalah mengkaji Desaind kelembagaan dalam kolaborasi pencegahan kematian ibu saat persalinan menggunakan model Collaborative Governance Ansel and Gash (2008) pada dimensi desain kelembagaan yang meliputi (a) partisipasi, (b) forum terbatas, (c) aturan dasar pendukung kolaborasi, dan (d), $\operatorname{transparan}^{(9)}$.

\section{BAHAN DAN METODE}

Metode penelitian ini metode penelitian kualitatif yang mana data hasil penelitian lebih berkenaan dengan interprestasi terhadap data yang ditemukan di lapangan, selanjutnya dikonstruksikan dalam suatu tema yang lebih bermakna dan mudah dipahami. Pendekatan yang digunakan dalam penelitian ini adalah fenomenologi yang berfokus pada deskripsi tentang pengalaman para informan.

Informan dalam penelitian ini terdiri atas Bhisa (dukun beranak), penyedia layanan kesehatan ibu dan anak, pengguna layanan, Bidan, kelompok Lansia, seluruhnya berjumlah 12 orang. Kemudian data dianalisis menggunakan analisis data Miles and Huberman yang terdiri atas data reduction, data display, dan conclusion 
drawing/verification ${ }^{(10)}$. Dalam menjamin kebsahan data temuan dilakukan Triangulasi sumber-sumber data yang berbeda dengan memeriksa bukti-bukti yang berasal dari sumber-sumber tersebut untuk membangun justifikasi tema-tema secara koheren.

\section{HASIL}

Hasil wawancara dan pengamatan yang dilakukan pada dasarnya disain kelembagaan pencegahan kematian ibu saat persalinan telah dilaksanakan dengan memperhatikan indikator dalam desain kelembagaan yang meliputi (a) Partisipasi, (b) Forum terbatas, (c) Aturan dasar pendukung kolaborasi, dan (d), Transparan.

\section{a. Partisipasi}

Pada indikator partisipasi berdasarkan reduksi hasil wawancara yang dilakukan partisipasi masyarakat dalam mendukung upaya pencegahan kematian ibu saat persalinan sangat jelas terlihat, dalam Peraturan Bupati Buton Selatan nomor 62 Tahun 2019 tentang Program Inovasi Bidang Kesehatan Gerakan Lanjut Usia Peduli Kesehatan Ibu dan Anak pada pasal 13 menyatakan keterlibatan Pemerintah Daerah, Kecamatan dan Desa, Kelompok Kerja Operasional, dan fasilitator.

Berdasarkan peraturan tersebut keterlibatan masyarakat umum sangat besar selain kader posyandu juga ada pelibatan ibuibu lansia dalam membantu pencegahan kematian ibu dengan membentuk tim pelaksana melalui surat keputusan kader lansia, yang terdiri beberapa tokoh-tokoh lansia. Masing-masing mereka memiliki tugas dan kewajiban masing-masing dalam pencegahan kematian ibu melahirkan, selain itu keterlibatan PKK, Dharma Wanita, dan juga tokoh adat dalam hal pengawasan demi suksesnya kegiatan ini sangat diharapkan.
Selain itu ada informan yang mengatakan bahwa bentuk partisipasi masyarakat adalah senantiasa dilibatkan dalam proses pengambilan kepustusan tentang bagaimana pencegahan kematian ibu saat persalinan yang juga melibatkan bidan, bhisa, dan ibu hamil sehingga program yang ditawarkan kemasyarakat dapat berjalan dengan baik.

Kemudian ada pula informan yang mengatakan bahwa kegiatan pencegahan kematian ibu saat persalinan di Kabupaten Buton Selatan terlebih dahulu melalui kesepakatan bersama antara pemerintah dan masyarakat, masyarakat ini di wakili oleh orang-orang yang paham betul dan berkompeten dalam urusan persalinan dalam hal ini bhisa (dukun beranak), kader lansia, dan kader posyandu, dan masyarakat pada umumnya.

Berdasarkan hasil wawancara dan pengamatan nampak bahwa pada umumnya masyarakat ikut berpartisipasi dalam kolaborasi pencegahan kematian ibu saat persalinan bentuk partisipasinya bermacammacam mulai adanya gerakan inovasi dengan melibatkan ibu-ibu lanjut usia, sampai pada pelibatan bhisa (dukun beranak). Hal ini dapat terjadi dikarenakan adanya dialog atau diskusi yang sehingga terbangun kesepahaman dan kesepakatan bersama bagaimana upaya pencegahan kematian ibu saat persalinan dilaksanakan.

\section{b. Forum terbatas}

Forum terbatas teah terbentuk dalam upaya pencegahan kematian ibu sala satunya adalah dengan membentuk Tim Pelaksana Kegiatan (TPK) berdasarkan SK nomor 07 Tahun 2019 kader Lansia yang beranggotakan para Lansia untuk membantu mengontrol dan mendata sasaran dilingkungan keluarga dan tetangganya yang terdiri dari ibu hamil,ibu bersalin,ibu nifas dan bayi baru lahir; menjadi narahubung dalam memberikan informasi kesehatan ibu 
hamil, ibu bersalin, ibu nifas kepada petugas kesehatan; melakukan sosialisasi gerakan lansia peduli kesehatan ibu dan anak kepada seluruh masyarakat; menggerakkan dan mengembangkan partisipasi, gotong royong dan swadaya masyarakat dalam membantu program lansia peduli kesehatan ibu dan anak; mendampingi ibu hamil, ibu bersalin, ibu nifas dan bayi mendapatkan pelayanan kesehatan di Puskesmas dan memantau konsumsi gizi; melaksanakan pencatatan dan pelaporan.

Selain itu mendampingi ibu hamil, ibu bersalin, ibu nifas dan bayi mendapatkan pelayanan kesehatan di puskesmas dan memantau konsumsi gizi; melaksanakan pencatatan dan pelaporan program gerakan lansia peduli kesehatan ibu dan anak kepada Kepala Desa atau Lurah serta bidan desa atau tenaga kesehatan lainnya yang ada di desa. Pembentukan kader lansia ini sebagai penerapan dari Peraturan Bupati nomor 62 tahun 2019 tentang program inovasi bidang kesehatan gerakan lanjut usia peduli kesehatan ibu dan anak.

Berdasarkan hasil wawancara bahwa pemerintah desa, para lansia dan bidan juga terlibat pemerintah daerah, tokoh adat dan orgaisasi kemasyarakatan turut berpartisipasi dalam pencegahan kematian ibu melahirkan. Partisipasi yang dilakukan jelas terlihat mulai dari kegiatan musyawarah dusun dalam membentuk kader lansia.

\section{c. Aturan Dasar pendukung kolaborasi}

Dalam upaya pencegahan kematian ibu saat persalinan tentu ada atururan aturan dasar yang dijalankan selain aturan-aturan adat yang berlaku secara turun temurun, antara lain Perbub Gerlap Lansia nomor 62 tahun 2019 kemudian diperkuat lagi dengan Peraturan Bupati nomor 62 Tahun 2019 tentang Program Inovasi Bidang Kesehatan Gerakan Lanjut Usia Peduli Kesehatan Ibu dan Anak pada pasal 13 menyatakan keterlibatan Pemerintah Daerah, Kecamatan dan Desa, Kelompok Kerja Operasional, dan fasilitator.

Komitmen terbangun berdasarkan aturan-aturan yang mengikat dan disepakati untuk dijalankan bersama. Faktor aturan adat sangat mendominasi saat pengambilan keputusan dalam memilih tempat persalinan, sehingga dibutuhkan diskusi yang melibatkan tokoh-tokoh adat melalui Kader Lansia agar komunikasi antara lembaga adat dan pemerintah dalam hal ini tenaga kesehatan dapat terjalin.

Berdasarkan hasil wawancara, salah seorang informan mengatakan, seringnya terjadi keterlambatan pengambilan keputusan dalam pemilihan tempat persalinan, masyarakat lebih memilih dan nyaman untuk melakukan persalinan dirumah dan jika harus melakukan persalinan di Fasilitas kesehatan harus menunggu dulu persetujuan dari bhisa (dukun) dan pimpinan adat (parabela) atau imam desa. Sehingga keterlambatan sampai di fasislitas kesehatan sering terjadi.

Terjadinya keterlambatan pengambilan keputusan disebabkan oleh keyakinan masyarakat bahwa segala sesuatu yang dimulai dari rumah maka harus diselesaikan dirumah sehingga masyarakat merasa tabu untuk meninggalkan rumah saat akan bersalin.

Upaya yang diilakukan adalah program pencegahan kematian ibu saat persalinan ini harus melibatkan tokoh-tokoh adat dan lansia sehingga sinergitas lembaga adat dan pemerintah dapat dibangun. Bagaimana aturan-aturan adat ini dapat sejalan dengan program pemerintah dan peraturan undangundang yang berlaku.

Adanya hambatan-hambatan dalam upaya pencegahan kematian ibu saat persalinan, sebab masih banyak berkembang dimasyarakat keyakinan-keyakinan atau kebiasaan persalinan dilakukan dirumah, walaupun gerakan ini melibatkkan tokoh-tokoh adat seperti Bhisa dan Parabela, namun keyakinan tersebut masih diyakini. 
Oleh karena itu kolaborasi antara kederkader posyandu, kader lansia dan seluruh elemen masyarakat harus dibarengi dengan penyatuan visi serta kesetaraan pemahaman dan pengetahuan para aktor kolaborasi.

\section{d. Transparan}

Transparansi dalam membangun kolaborasi dilakukan atas dasar saling menghargai antar aktor kolaborasi, saling terbuka mengenai anggaran dan untung rugi kolaborasi. Transparan dalam artian kita saling terbuka jangan ada yang ditutuptutupi, pemerintah dan masyarakat atau lebih khusus keluarga ibu hamil harus sejalan.

Masyarakat harus jujur memberikan informasi terkait kondisi atau keberadaan ibu hamil yang ada dilingkungannya sehingga pendampingan dan pemberian informasi tentang kesehatan ibu hamil dapat diberikan. Berdasarkan hasil wawancara bahwa masyarakat sudah mulai paham akan pentingnya kesehatan ibu, masyarakat juga ikut terlibat dalam pemberian informasi mengenai kondisi ibu hamil.

Selain itu toko-tokoh lansia ikut ambil bagian dalam hal pendampingan pemberian kesadaran akan pentingnya kesehatan ibu dan bayi yang dikandung. Pertemuan ini dalam kelas lansia, pertemuan informal dimana pihak pemerintah, lansia dan Bhisa berkunjung ke rumah ibu hamil serta pembahasan mengenai tanda-tanda maupun bahaya melahirkan apabila terjadi penundaan.

Saling keterbukaan informasi dan saling percaya antar ibu hamil, bhisa, dan bidan desa harus terus terjalin demi pencegahan akan hal-hal yang tidak diinginkan bersama. Ibu hamil dan keluarganya harus paham dan percaya pada petugas kesehatan untuk mau melakukan persalinan di fasilitas kesehatan. Inilah peran Parabela dan dan Bhisa. Bagaimana dengan peran dan pengaruhnya ditengah-tengah masyarakat dapat meyakinkan ibu hamil dan keluarganya.
Ada beberapa informan mengatakan bahwa memang masih ada sebagian masyarakat sudah mau mengikuti saran-saran dari para petugas kesehatan dengan melibatkan Bhisa sebagai media komunikasi bagi ibu hamil dan keluarganya dan ini juga dilakukan melalui pendekatan budaya.. memang ada beberapa ibu saat mengontrol kehamilannya di Posyandu senantiasa aktif, namun pada saat masa persalinan masih ada yang memilih dirumah.

Transparan dalam kolaborasi pencegahan kematian ibu bersalin sudah dilakukan, namun perlu ada penguatanpenguatan lagi baik dari pemerintah dan masyarakat untuk mendukung upaya pencegahan kematian ibu saat persalinan. Walaupun keterbukaan informasi dan pelibatan masyarakat masih saja ada masyarakat yang belum sadar akan pentingnya menjaga persalinan agar aman dan selamat. Pemahaman yang dimiliki masyarakat tentang merawat kehamilan belum sejalan dengan perilaku yang masih melakukan persalinan diluar fasilitas kesehatan.

\section{PEMBAHASAN}

Desaind kelembagaan kolaborasi pencegahan kematian ibu merupakan hal yang mutlak ditengah-tengah masyarakat sebab melibatkan masyarakat secara luas dan terintegrasi. Partisipasi masyarakat terbangun bukan sekedar pemakluman tetapi partisipasi aktif yang dibutuhkan dan hal utama dalam membangun partisipasi penuh masyarakat adalah kesetaraan antar aktor kolaborasi ${ }^{(11)}$.

Desain kelembagaan meliputi (a) Partisipasi, (b) Forum terbatas, (c) Aturan dasar pendukung kolaborasi, dan (d), Transparan

\section{a. Partisipasi}

Partisipasi merupakan faktor kunci dalam menjamin keberhasilan program pembangunan. Partisipasi yang dimaksud 
adalah memberikan kesempatan seluasluasnya kepada masyarakat untuk terlibat dalam proses pembangunan dan dapat meinkmati hasil pembangunan sesuai dengan kapasitasnya. Partisipasi dapat mempercepat lahirnya program-program yang dapat memberikan ruang dan akses lebih luas kepada masyarakat serta menentukan arah kebijakan pembangunan.

Partisipasi dibangun atas dasar kesetaraan peran, para aktor kolaborasi terlibat langsung dalam pengambilan keputusan "bukan sekedar" berkonsultasi pada lembaga publik merupakan fokus dalam collaborative gobernance, hal ini dapat dilihat dalam kerjasama yang dibangun antara pemerintah dan masyarakat pada Peraturan Bupati nomor 62 Tahun 2019 tentang Program Inovasi Bidang Kesehatan Gerakan Lanjut Usia Peduli Kesehatan Ibu dan Anak pada pasal 13 menyatakan keterlibatan Pemerintah Daerah, Kecamatan dan Desa, Kelompok Kerja Operasional, dan fasilitator.

Dalam kaitannya dengan upaya pencegahan kematian ibu saat persalinan adanya pelibatan unsur pimpinan adat (parabela) untuk ikut serta dalam program ini dengan tujuan agar aturan-aturan adat istiadat atau keyakinan masyarakat yang secara turun temurun terus dilaksanakan masyarakat agar dilakukan penyesuaian-penyesuaian sesuai dengan kondisi dan peraturan perundang undangan yang berlaku serta perkembangan ilmu pengetahuan. Bhisa dan Para tokoh lansia sangat disegani dan dihargai masyarakat dapat menjadi corong informasi terkait masalah perawatan kehamilan.

Hal tersebut sejalan dengan pemikiran Islamy bahwa terdapat dua prinsip dasar yang menjadi perhatian dalam partisipasi yaitu; prinsip kesepakatan bersama dan prinsip persamaan kedudukan/kesetaraan. Kesepakatan bersama adalah keputusan yang diambil atas dasar persetujuan atau kesepakatan bersama. Kesepakatan bersama bersifat mengikat dan tidak dapat diganggu gugat. Hasil kesepakatan bersama biasanya diambil berdasar hasil musyawarah mufakat yang telah dipertimbangkan dengan baik dan benar. Kesepakatan bersama merupakan ketentuan, ketetapan, dan penyelesaian yang dilakukan sekelompok orang terhadap suatu hal atau permasalahan. Semua pihak diharapkan dapat menerima kesepakatan bersama dengan ikhlas, bertanggung jawab, dan lapang dada. Sedangkan prinsip persamaan kedudukan adalah perihal kesamaan tingkatan. Dengan demikian prinsip persamaan kedudukan disini adalah suatu kondisi dimana dalam perbedaan dan keragaman yang ada pada aktor kolaborasi tetap memiliki satu kedudukan yang sama dan satu tingkatan Hierarki. termasuk perlakuan yang sama dalam kolaborasi tanpa membedakan jenis kelamin, keturunan, kekayaan, suku bangsa, dan lainnya. Kedua prinsip tersebut menunjukan adanya peran aktif para aktor baik ditingkat pemerintah, swasta maupun masyarakat dalam hal ini lembaga adat ${ }^{(12)}$.

\section{b. Forum Terbatas}

Secara teoritis collaborative governance dikelolah oleh sebuah badan kerjasama, badan kerjasama merupakan suatu forum yang melaksanakan suatu kerjasama yang anggotanya merupakan perwakilan yang dipercaya untuk melakukan kerjasama. Obyek kerjasama meliputi seluruh urusan yang menjadi tanggung jawab pemerintah daerah otonom, asset daerah dan potensi daerah dan penyediaan layanan umum ${ }^{(11)}$.

Dalam upaya pencegahan kematian ibu saat persalinan telah terbentuk sebuah forum yang berpartisipasi aktif dalam upaya ini yaitu kader posyandu dan kader lansia. Forum ini terbentuk secara alamiah dari diskusi-diskusi yang dibangun dalam melaksanakan program kesehatan ibu dan anak namun resmi terbentuk berdasarkan Peraturan Bupati nomor 62 Tahun 
2019.forum ini terdiri atas para bidan, tenaga kesehatan, ibu-ibu, tokoh lansia dan masyarakat yang memiliki perhatian terhadap kesehatan ibu dan anak.

Forum ini juga melibatkan pimpinan adat, Pimpinan adat (Parabela) memiliki peran dalam pemerintahan adat, umumnya Parabela sangat dihormati mereka diperlakukan sangat istimewa bahkan sangat mengakar dalam masyarakat karena mereka diangkat oleh adat dan sesuai dengan normanorma tradisional ${ }^{(12)}$.

\section{c. Aturan Dasar pendukung Kolaborasi}

Kolaborasi merupakan proses kolektif dalam pembentukan sebuah kesatuan yang didasari oleh hubungan saling menguntungkan (mutualisme) dan adanya kesamaan tujuan dari organisasi atau individu-individu yang memiliki sifat otonom. Mereka saling berinteraksi melalui negosiasi baik bersifat formal maupun informal dalam suatu aturan yang disepakati bersama dan rasa saling percaya. Walaupun hasil atau tujuan akhir dari sebuah proses kolaborasi tersebut mungkin bersifat pribadi, tetapi tetap memiliki hasil atau keuntungan lain yang bersifat kelompok ${ }^{(11)}$.

Dalam upaya pencegahan kematian ibu saat persalinan kolaborasi yang terjalin merupakan hubungan kepercayaan dan komitmen serta kesatuan tujuan. Mereka berdiskusi dan membangun kesepakatan baik secara formal maupun informal dalam sebuah aturan yang disepakati yaitu aturan adat dan aturan perundang-undangan yang berlaku. Berdasarkan hasil penelitian yang dilakukan Andriani bahwa idelanya berdasarkan peraturan perundang-undangan bahwa setiap ibu harus melakukan persalinan pada fasiitas kesehatan, namun dalam masyarakat tradisonal mereka akan nyaman melakukan persalinan di luar rumah jika mereka didampingi oleh bhisa (dukun) ${ }^{(13)}$, jadi kolaborasi inilah yang digalakan dalam upaya pencegahan kematian ibu.

Bhisa sangat dipercaya sosok yang sangat dipercaya masyarakat karena memberikan perlakuan khusus kepada ibu hamil hingga nifas Bhisa mengurus ibu hamil dengan telaten, sabar sehingga ibu hamil merasa nyaman dan rileks, inilah peran bhisa yang diyakini memliki kemampuan supranatural yang dipercaya masyarakat bisa memudahkan proses kehamilan, dan itu tidak dimiliki oleh bidan ${ }^{(13)}$. Jadi kolaborasi ini akan sangat penting dalam membangun sinergi antara bidan dan dukun.

\section{d. Transparan}

Menurut Innes dan Booher, dialog yang dilakukan dalam proses kolaborasi harus merupakan dialog otentik (Authentic dialogue), bukan retoris atau ritual. Masingmasing pembicara memiliki legitimasi, berbicara dengan sungguh-sungguh, membuat pernyataan yang dapat difahami oleh orang lain, serta menyampaikan pernyataan yang akurat. Dialog demikian akan menghasilkan reciprocity, relationships, learning, and creativity ${ }^{(14)}$. Dengan demikian proses ini akan dampak yang positif bagi aktor kolaborasi. Prinsip dasar dalam kolaborasi adalah transparan proses, penyatuan dan keterwakilan, dan kesatuan pemahaman dan kemampuan dalam pengambilan keputusan.

Keterbukaan informasi dan komunikasi sangat penting dilakukan. Masyarakat dalam hal ini ibu hamil dan keluarganya bebas memperoleh informasi tentang kesehatan kehamilan dan ibu hamil juga harus terbuka akan kondisi kehamilannya, kendala-kendala dalam proses persalinan, sampai kepada rencana dimana melakukan persalinan. namun ada beberapa hambatan-hambatan terkait penyatuan persepsi antara bhisa dan tenaga kesehatan terkait masaalah adat dan kebiasaan ritual yang masih dijadikan alasan 
untuk melakukan persalinan dirumah. Ritusl proses perslinan masih dianggap sakral bukan sesuatu yang dilakukan diluar rumah (fasilitas kesehatan) sehingga tidak jarang ibu hamil banyak yang memutuskan untuk melakukan persalinan dirumah.

Sehingga dapat ditarik kesimpulan bahwa transparansi ini dibangun atas dasar kebebasan memperoleh informasi. Informasi yang berkaitan dengan kepentingan seluruh masyarakat yang secara langsung dapat diperoleh oleh mereka yang membutuhkan dalam hal ini ibu hamil. Keterbukaan pemerintah dalam membuat kebijakan pencegahan kematian ibu saat persalinan agar dapat tersosialisasi dengan baik dengan melibatkan para pemimpin adat dan Bhisa.

\section{KESIMPULAN}

Desain kelembagaan dalam kolaborasi pencegaha kematian ibu saat persalinan pada dasarnya telah terbentuk hal ini dapat dilihat dari partisipasi masyarakat yang begitu besar yang didasarkan atas kesetaraan dan berbagi pemahaman dari para aktor kolaborasi. Kemudian adanya forum terbatas yang terbangun secara alamiah dan dari diskusi-diskusi yang dilakukan baik secara formal maunpun informal yang pada akhirnya terlegitimasi dengan aturan-aturan dasar pendukung kolaborasi yang menggabungkan antara aturan-aturan adat dan kebiasaan yang dilakukan secara turun temurun juga peraturan perundang-undangan yang berlaku walauoun diakui masih saja ada benturan-benturan dimasyarakat sehingga perlu ditingkatkan keterbukaan informasi dan komunikasi, serta saling berbagi pemahaman tentang upaya pencegahan kematian ibu saat persalinan.

\section{DAFTAR RUJUKAN}

1. Achadi EL. Kematian Maternal dan
Neonatal di Indonesia. FKM UI pada Rakernas. 2019;

2. Rininta Andriani, Muh. Syafar RMT\& S. DETERMINANTS OF MATERNAL MORTALITY IN BUTON DISTRICT SOUTHEAST SULAWESI PROVINCE. Int J Acad Res Reflect [Internet]. 2017; Vol. 5(No. 4):19. Available from: https://www.idpublications.org/wpcontent/uploads/2017/06/Full-PaperDETERMINANTS-OF-MATERNALMORTALITY-IN-BUTONDISTRICT-SOUTHEAST.pdf

3. Sultra D. Profil Kesetahan Sulawesi Tenggara Tahun 2019. 2020.

4. Kesehatan D. Profil Kesehatan Kabupaten Buton Selatan. 2019.

5. Andriani R. Pencegahan Kematian Ibu Saar Hamil Dan Melahirkan Berbasis Komunitas [Internet]. Deepublish; 2019. Available from: https://books.google.co.id/books?id=r hieDwAAQBAJ

6. Sari MM, Nurkamila N, Mawati ED. Faktor-Faktor Yang Mempengaruhi Kepatuhan Ibu Hamil dalam Melakukan Pemeriksaan Kehamilan di Puskesmas Cibungbulang Kabupaten Bogor Provinsi Jawa Barat Tahun 2018. Promot J Mhs Kesehat Masy. 2018;1(2).

7. Kemenkes R. PMK No.97 Tahun 2014 Tentang Pelayanan Kesehatan. Artikel [Internet]. 2014; [cited 2018 Jan 7]; 38. Available from: https://id.search.yahoo.com/search?p= PMK+No.97+th+2014+tentang+pelay anan+kesehatan+masa+sebelum+hami $1 \% 2 \mathrm{C}+$ masa+hamil\%2C+persalinan $+\mathrm{d}$ an+sesudah+melahirkan \&fr=yfpt\&fp $=1 \&$ toggle $=1 \&$ cop=mss\&ei $=\mathrm{UTF}$ $-8 \% 0$ Akesga.kemkes.go.id 
8. La Ode Syaiful Islamy A, Haning MT, Allorante AI. THE MODEL OF COLLABORATIVE GOVERNANCE IN TOURISM DEVELOPMENT AT BUTON DISTRICT. Int J Acad Res Reflect. 2017;

9. Ansell C, Gash A. Collaborative Governance in Theory and Practice. $\mathrm{J}$ Public Adm Res Theory [Internet]. 2008 Oct 1;18(4):543-71. Available from:

https://doi.org/10.1093/jopart/mum032

10. Miles MB, Huberman M. Analisis Data Kualitatif: Buku tentang sumbersumber baru. Univ Indones Jakarta. 1992;

11. La Ode Syaiful Islamy H. DESIGN INSTITUTIONS IN COLLABORATION DEVELOPMENT. 2018;6(4):47-54.
12. La Ode Syaiful Islamy $\mathrm{H}$. Collaborative Governance Konsep Dan Aplikasi. Deepublish; 2018.

13. Andriani R. The relationship between the choice of place of delivery and childbirth labor with the incidence of infant mortality in Sorawolio community health center working area of Baubau City, Indonesia. J Public Health Africa. 2019;10.

14. Innes JE, Booher DE. Collaborative dialogue as a policy making strategy. 2000; 